\title{
Should Alvarado and Ohmann scores be real indicators for diagnosis of appendicitis and severity of inflammation?
}

\author{
Eyüp Murat Yılmaz, M.D., ${ }^{1}$ Mücahit Kapçı, M.D., ${ }^{2}$ Sebahattin Çelik, M.D., ${ }^{3}$ \\ Berke Manoğlu, M.D., ${ }^{4}$ Mücahit Avcil, M.D., ${ }^{2}$ Erkan Karacan, M.D. ${ }^{1}$ \\ ${ }^{1}$ Department of General Surgery, Adnan Menderes University Faculty of Medicine, Aydın-Turkey \\ ${ }^{2}$ Department of Emergency Medicine, Adnan Menderes University Faculty of Medicine, Aydın-Turkey \\ ${ }^{3}$ Department of General Surgery, Van Yüzüncu Yıl University Faculty of Medicine, Van-Turkey \\ ${ }^{4}$ Department of General Surgery, Aydın State Hospital, Aydın-Turkey
}

\section{ABSTRACT}

BACKGROUND: Acute appendicitis is one of the most common causes of abdominal pain seen in surgical clinics. Although it can be easily diagnosed, the picture may be confusing, particularly in premenopausal women and the elderly. The present study is an evaluation of 2 of the current scoring systems with respect to accurate diagnosis of the disease and indication of inflammation severity.

METHODS: A total of 105 patients diagnosed with acute appendicitis were included in the study. Subsequent to Alvarado and Ohmann scoring, ultrasonography image was obtained and appendectomy was performed. A unique intraoperative severity scoring system was used to measure severity of inflammation and to compare Alvarado and Ohmann scoring system results to assess accuracy of predictive value for acute appendicitis.

RESULTS: Moderate positive correlation was found between Alvarado score and Ohmann score $(r=0.508 ; p<0.00 \mathrm{I})$. Rate of Alvarado score successfully predicting diagnosis of acute appendicitis based on histopathological results was statistically significant $(p=0.027)$, while rate of Ohmann score was not statistically significant $(p=0.807)$. Correlation between both scores and grading of inflammation performed during the operation was weak, but statistical significance was observed between Alvarado scoring system and intraoperative severity scoring $(r=0.30 ; p=0.002)$. No statistical difference was observed between Ohmann scoring and intraoperative severity scoring $(r=0.09 ; p=0.384)$.

CONCLUSION: Alvarado score is better able to predict acute appendicitis and provide an idea of severity of inflammation. Ohmann score is more useful to provide guidance and eliminate acute appendicitis from consideration when conditions are more uncertain and obscured.

Keywords: Alvarado; appendicitis; inflammation; Ohmann.

\section{INTRODUCTION}

Acute appendicitis is the most common clinical diagnosis in general surgery clinics for patients who require urgent operation due to abdominal pain. ${ }^{[I]}$ Diagnosis is generally made based on history, symptoms, physical examination, and labo-

Address for correspondence: Eyüp Murat Yılmaz, M.D.

Adnan Menderes Üniversitesi Tıp Fakültesi, Genel Cerrahi Anabilim Dalı, 09100 Aydın, Turkey

Tel: +90 256 - 2121850 E-mail: drmyilmaz80@gmail.com

Qucik Response Code

Ulus Travma Acil Cerrahi Derg

2017;23(I):29-33

doi: $10.5505 /$ tjtes.2016.89894

Copyright 2017

TJTES ratory findings. Ultrasonography (USG) and computed tomography (CT) images should be considered in evaluation of acute appendicitis, and in some cases, advanced imaging may also be needed. ${ }^{[2]}$ Gynecological emergencies, particularly in premenopausal women, such as pelvic inflammatory disease, ovarian cyst rupture, and tubal pregnancy mimic acute appendicitis and may be mistaken for acute appendicitis at a rate of $40 \% .{ }^{[2,3]}$ In addition, diseases that do not require surgery, such as urological disease, colonic diverticulitis, and epiploic appendicitis, may be confused with acute appendicitis. Since diagnostic markers for acute appendicitis are limited, advanced imaging methods should be used for these patients. Negative appendectomy rate has been reported as $12 \%$, and undiagnosed perforated acute appendicitis rate has been reported as $3.4 \%$ in the literature. ${ }^{[4]}$ Patients are exposed to unnecessary surgical stress in cases of negative appendectomy while other diagnoses may be ignored. When diagnosis is clinically 
or radiologically suspected acute appendicitis, or if it is omitted altogether, more complex clinical picture may develop. In order to minimize these cases, various diagnostic scoring systems, such as Alvarado, Ohmann, Eskelinen and Lintula scores, have been developed for use in daily practice. ${ }^{[5,6]}$

Alvarado score, which is based on symptoms, physical examination, and laboratory findings, has been in use since 1986. It is a simple and inexpensive test that can be applied for patients with right lower quadrant pain..$^{[5]}$ Ohmann score is another easily applied scoring system to explore possibility that patient with abdominal pain has appendicitis. ${ }^{[7]}$ The present study examined efficacy of both systems for diagnosis of appendicitis and assessment of severity of inflammation.

\section{MATERIALS AND METHODS}

This prospective study was conducted between November I, 2014 and July 3I, 20I5 with the permission of the ethics committee of Adnan Menderes University Faculty of Medicine. Total of 105 patients who came to Adnan Menderes University emergency service and were prediagnosed with acute appendicitis were included. Alvarado score (Table I) and Ohmann score (Table 2) were calculated. Abdominopelvic examinations and laboratory findings were evaluated, and all patients underwent abdominal USG. All patients who underwent surgery at Adnan Menderes University Faculty of Medicine General Surgery Clinic provided written informed consent. Intraoperative severity scoring system was used during operation to determine severity of inflammation (Table 3). Definitive diagnosis was made histopathologically after surgery. Patients who declined surgery, who did not want to participate in the study, who were not operated on due to doubt in the diagnosis of appendicitis, or who were discharged after follow-up and had regression of symptoms were excluded from the study.

The study was explained to all patients who underwent surgery and their relatives, and written, informed consent was provided for the findings to be used for scientific purposes.

Alvarado scoring system consists of 8 parameters, and rate of accuracy varies between $78 \%$ and $82 \%{ }^{[8,9]}$ Surgery is recommended for patients who receive score of 7 or more, and follow-up is suggested for those whose score is less than 7. ${ }^{[10]}$ Ohmann scoring system also consists of total of 8 parameters. Patients whose score is less than 6.5 are evaluated as "low probability of appendicitis," while score of between 6.5 and 12 is interpreted as "may have appendicitis" and followup is recommended. Score of 12 or more is seen as "most likely has appendicitis." ${ }^{[1]}$

Although Mannheim Peritonitis Index is a scoring system used to measure severity of peritonitis, there is no system specific to appendicitis that has generally proven to be valid for assessment of severity of intraoperative inflammation. ${ }^{\left[{ }^{[2]}\right]}$ For
Table I. Alvarado scoring

\begin{tabular}{lc}
\hline Feature & Score when present \\
\hline Migration of pain & $\mathrm{I}$ \\
Anorexia & $\mathrm{I}$ \\
Nausea & $\mathrm{I}$ \\
Tenderness in right lower quadrant & 2 \\
Rebound pain & $\mathrm{I}$ \\
Elevated temperature & $\mathrm{I}$ \\
Leukocytosisa & 2 \\
Shift of white blood cell count to lefta & $\mathrm{I}$ \\
Total (maximum) & 10 \\
\hline
\end{tabular}

Table 2. Ohman scoring

\begin{tabular}{lc}
\hline Parameter & Result \\
\hline Tenderness in right lower quadrant & 4.5 points \\
Rebound tenderness, contralateral & 2.5 points \\
Dysuria & 2.0 points \\
Constant pain & 2.0 points \\
White blood cell $>10000 / \mathrm{mL}$ & I.5 points \\
Patient aged $>50$ years & 1.5 points \\
Local guarding & I.0 points \\
Shifting pain & 1.0 points \\
Total $<6.5$ & Acute appendicitis \\
& unlikely \\
Total $6.5-12$ & Finding unclear \\
& (observation) \\
Total $>12$ & Acute appendicitis \\
& very likely (operation) \\
\hline
\end{tabular}

Table 3. Intraoperative severity scoring

\begin{tabular}{lc}
\hline Major finding & Points \\
\hline Negative appendectomy & 0 \\
Increased vascularity & 1 \\
Perforated appendix & 2 \\
Perforated appendix + phlegmonous appendicitis & 3 \\
\hline
\end{tabular}

the present study, simple grading system based on intraoperative macroscopic findings was used to evaluate inflammation. Intraoperative severity scoring system awarded 0 points to patients with negative appendicitis, I point to patients with increase in vascularity only, 2 points to patients with perforated appendix, and 3 points to those with perforation and phlegmonous appendicitis. 
This study is an investigation of correlation between Alvarado and Ohmann scores and inflammation severity, conducted with the intent to contribute to the available statistics by identifying the contributions of these scoring systems to accurate diagnosis of acute appendicitis in terms of predictive sensitivity and evaluation of inflammation severity.

\section{Statistical Analysis}

Continuous and categorical data were analyzed using SPSS software (version 20.0; IBM Corp., Armonk, NY, USA). Descriptive statistics were expressed as numbers and percentages for categorical data, while average standard deviation and median with minimum-maximum were used to express continuous data, depending on normal distribution. As it was determined that Alvarado and Ohmann scores were not normally distributed (Kolmogorov-Smirnov test), these variables and ordinal variable of intraoperative severity score were compared using Kruskal-Wallis test. The possible factors determined in the previous analyses were used in multivariate analysis, and logistic regression analysis was performed to analyze independent estimators in prediction of appendicitis as determined by pathology results. Agreement between pathology results and results of USG was investigated using Kappa statistic correlation test. Cases in which type I errors were below $5 \%$ were accepted as statistically significant.

\section{RESULTS}

\section{Patients and Treatments}

A total of 105 patients were included in the study; $50.48 \%$ $(n=53)$ were female and $49.52 \%(n=52)$ were male. Open appendectomy was performed in $4 \mathrm{I}$ cases $(39.10 \%)$ and laparoscopic technique was used in 64 cases $(60.90 \%)$. Median age was 31 years $(\min =16, \max =76$ years). Median age of female patients was 28 years, while that of males was 34 years.

Relationship between Alvarado and Ohmann scoring systems Moderate positive correlation was found between Alvarado score and Ohmann score $(r=0.508 ; p<0.00 \mathrm{I})$. According to histopathological results, rate of accurate prediction of acute appendicitis diagnosis according to Alvarado scoring system was statistically significant $(p=0.027)$, while rate of prediction using Ohmann score was not statistically significant $(p=0.807)$.

When patient white blood cell (WBC) count was evaluated against scoring system results, difference for Alvarado score was statistically significant, but only weak positive correlation was observed $(r=0.279 ; p=0.004)$. No statistical significance was observed for Ohmann scoring system based on WBC. $(r=-0.021 ; p=0.834)$ (Figs. I, 2).

\section{Intraoperative Severity Score}

Link between 2 scores and the intraoperative severity score was determined to be weak; however, statistical significance

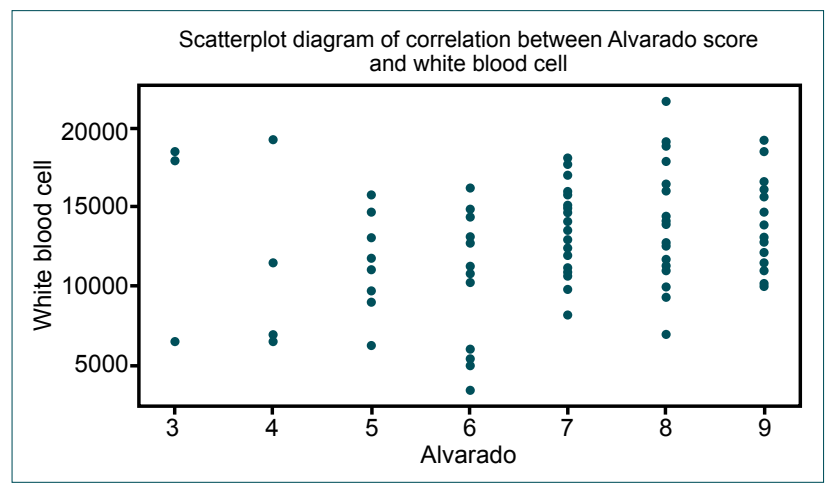

Figure 1. Relationship between Alvarado score and white blood cell count.

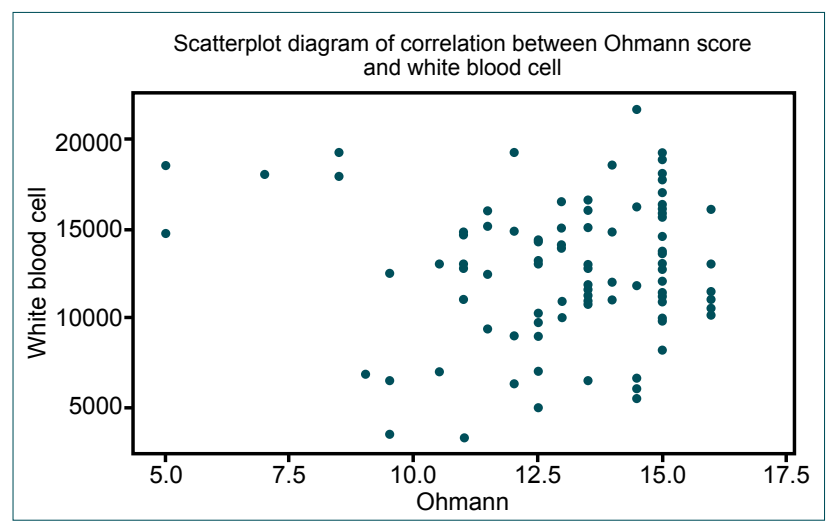

Figure 2. Relationship between Ohmann score and white blood cell count.

was observed between Alvarado score and intraoperative severity score $(r=0.30 ; p=0.002)$ Increase in Alvarado score was reflected in increase in intraoperative severity, but this link was weak. No statistical significance was found between Ohmann scoring system and intraoperative severity scoring $(r=0.09 ; p=0.384)$. When patients were divided into 4 groups according to intraoperative severity scoring (0-3), significant difference was observed based on Alvarado score $(p=0.016)$. Patients who had intraoperative severity score of 0 , I, or 2 had median Alvarado score of 7 , and patients with intraoperative severity score of 3 had median Alvarado score of 8 . No significant difference was observed between these 4 groups according to Ohmann score $(\mathrm{p}=0.457)$.

\section{Accuracy of USG}

Sensitivity of USG based on histopathology results was $80.22 \%$ and specificity was $92.86 \%$. USG consistency with final histopathology determination was $48.3 \%$.

\section{DISCUSSION}

Acute appendicitis is the most common cause of abdominal pain cases seen in emergency services and surgery clinics, but it can be difficult to make definitive diagnosis, particularly in premenopausal women and elderly patients. ${ }^{[13]}$ Genitourinary diseases and gynecological disorders can have similar symp- 
toms and may be easily confused with appendicitis. ${ }^{[2,14]}$ Delayed diagnosis and intervention in case of acute appendicitis can lead to clinical picture of perforation, sepsis, and increase in morbidity and mortality. On the other hand, cases of appendectomy performed with diagnosis of appendicitis and negative appendicitis result determined intraoperatively and histopathologically are reported to be at rate of $12 \%$ to $40 \%$ in the literature. ${ }^{[4,15]}$ Many authors have reported that this rate is acceptable in order to decrease rate of perforation to minimal. ${ }^{[16]}$ Though there are now advanced imaging methods, such as USG and CT, many diagnostic scoring systems have been developed to help decrease rate of negative appendectomies. The present study compared predictive diagnosis of acute appendicitis according to Alvarado and Ohmann scoring systems and correlation to severity of inflammation.

Alvarado score is simple test that is accepted as having high sensitivity and specificity. ${ }^{[9,17]}$ Many studies have been performed affirming general validity for predicting acute appendicitis. Dumlu et al. ${ }^{[18]}$ stated in a study they performed that as Alvarado score increased, inflammation also increased. In a study performed by Kariman et al., ${ }^{[19]}$ patients who presented with acute abdominal pain and had result greater than 7 on Alvarado scoring system were $93 \%$ more likely to be diagnosed with acute appendicitis, while patients with score below 7 had $26 \%$ chance of being diagnosed with acute appendicitis. Therefore, one may have great confidence in guidance of tool in instance of Alvarado score of 7 or more, but patients with lower score should be approached cautiously. The Alvarado score rate of accurate prediction of diagnosis of acute appendicitis was determined to be statistically significant in our study $(p=0.027)$. Moreover, statistical difference, though weak positive correlation, was observed between Alvarado scoring system and WBC $(r=0.279 ; p=0.004)$. Significance of Alvarado scoring in prediction of acute appendicitis is consistent in the literature. We wanted to investigate correlation to degree of clinical severity of inflammation. We did not use Mannheim Peritonitis Index, a scoring system used for years in order to determine severity of peritonitis, as it is not specific to appendicitis. ${ }^{[12]}$ In order to determine severity of intraoperative macroscopic clinical inflammation, we used a basic but useful intraoperative severity scoring system in this study. Other authors have created and published studies with similar, unique macroscopic severity scores in the literature. Sousa-Rodrigues et al. ${ }^{[6]}$ used 4 inflammation groupings in their study. A scoring system was established to measure minimal changes: necrosis without perforation, perforation, perforation with limited peritonitis, and generalized peritonitis. No strong correlation was observed in their findings despite statistical significance. Dumlu et al. ${ }^{[18]}$ classified patient groups in terms of severity of inflammation as having acute appendicitis, perforated appendix, perforation + phlegmonous appendicitis, or perforated appendix and negative appendectomy. Correlation was observed between severity of inflammation and Alvarado scoring system. In our study, 0 points were given to patients with negative appendicitis, I point to patients with increase in vascularity only, 2 points to patients with perforated appendix, and 3 points to those with perforated appendix and phlegmonous appendicitis. In our study, link between Alvarado score and intraoperative severity scoring was found to be weak, though there was statistical significance between them $(r=0.30 ; p=0.002)$. In addition, when Alvarado score increased, intraoperative severity score was observed to increase. For this reason, according to the results of our study, we believe that Alvarado score may be a means to both predict appendicitis and estimate severity of inflammation.

Ohmann scoring system was developed by Ohmann et al. ${ }^{[20]}$ and it is a useful and easy test employed in diagnosis of acute appendicitis. Kiyak et al. ${ }^{[7]}$ reported in their study that Ohmann scoring system may be more successful at excluding diagnosis of acute appendicitis. Zielke et al. ${ }^{[20]}$ stated in a multicenter study that Ohmann score may be beneficial in predicting diagnosis of acute appendicitis. In our study, moderately positive correlation was found between Alvarado score and Ohmann score $(r=0.50 ; p<0.001)$. However, diagnosis of appendicitis by Ohmann scoring system was not found to be statistically significant according to histopathological results $(p=0.807)$. Another study also reported that Ohmann score was better at excluding acute appendicitis, rather than predicting it. ${ }^{[2]}$ No statistical significance was observed in relationship to WBC. $(r=-0.021 ; p=0.834)$. Weak link was found between WBC and intraoperative severity score, but no statistical significance was observed $(r=0.09$; $p=0.384$ ). We believe that the reason for this is higher specificity of Ohmann scoring system. Exclusion of diagnosis of acute appendicitis can be made for patients with low Ohmann score; however, higher score merits further examination. We believe that there is no correlation between Ohmann score and severity of inflammation.

Doubt regarding diagnosis of appendicitis remains, despite availability of several scoring systems. The easiest and most widely known of these, the Alvarado scoring system, provides a path to diagnosis of acute appendicitis. It can also provide clinician with idea about severity of inflammation. Ohmann scoring system is generally used for exclusion of acute appendicitis rather than prediction and it does not seem sufficiently sensitive. Nor does it give much idea about severity of inflammation. Further studies with wider context and more patients are needed.

No financial funding was provided for this study.

Conflict of interest: None declared.

\section{REFERENCES}

1. Park JS, Jeong JH, Lee JI, Lee JH, Park JK, Moon HJ. Accuracies of diagnostic methods for acute appendicitis. Am Surg 2013;79:101-6.

2. Antevil J, Rivera L, Langenberg B, Brown CV. The influence of age and 
gender on the utility of computed tomography to diagnose acute appendicitis. Am Surg 2004;70:850-3.

3. McKay R, Shepherd J. The use of the clinical scoring system by Alvarado in the decision to perform computed tomography for acute appendicitis in the ED. Am J Emerg Med 2007;25:489-93. Crossret

4. Toorenvliet BR, Wiersma F, Bakker RF, Merkus JW, Breslau PJ, Hamming JF. Routine ultrasound and limited computed tomography for the diagnosis of acute appendicitis. World J Surg 2010;34:2278-85. Crossret

5. Konan A, Hayran M, Kılıç YA, Karakoç D, Kaynaroğlu V. Scoring systems in the diagnosis of acute appendicitis in the elderly. Ulus Travma Acil Cerrahi Derg 2011;17:396-400. Crossre

6. Sousa-Rodrigues CF, Rocha AC, Rodrigues AK, Barbosa FT, Ramos FW, Valóes SH. Correlation between the Alvarado Scale and the macroscopic aspect of the appendix in patients with appendicitis. Rev Col Bras Cir 2014;41:336-9. Crossre]

7. Kıyak G, Korukluoğlu B, Özgün Y, Devay AÖ, Kuşdemir A. Evaluation of Ohmann and Eskelinen scores, leukocyte count and ultrasonography findings for diagnosis of appendicitis. Ulus Travma Acil Cerrahi Derg 2009;15:77-81.

8. Alvarado A. A practical score for the early diagnosis of acute appendicitis. Ann Emerg Med 1986;15:557-64. Crossre

9. Nirajlal B, Gabriel R, Anand R, Sohil AK. Evaluation of Alvarado score in acute appendicitis: A prospective study. The Internet Journal of Surgery 2007;9.

10. İnan $\mathrm{M}$, Tulay $\mathrm{SH}$, Besim $\mathrm{H}$, Karakaya J. The value of ultrasonography and its' comparison with Alvarado scoring system in acute appendicitis. Ulusal Cerrahi Dergisi 2011;27:149-53. Crossre

11. Ohmann C, Franke C, Yang Q, Margulies M, Chan M, van Elk PJ, et al. Diagnostic score for acute appendicitis. [Article in German] Chirurg 1995;66:135-41. [Abstract]
12. Bosscha K, Reijnders K, Hulstaert PF, Algra A, van der Werken C. Prognostic scoring systems to predict outcome in peritonitis and intra-abdominal sepsis. Br J Surg 1997;84:1532-4. Crossre

13. Stephens PL, Mazzucco JJ. Comparison of ultrasound and the Alvarado score for the diagnosis of acute appendicitis. Conn Med 1999;63:13740 .

14. N N, Mohammed A, Shanbhag V, Ashfaque K, S A P. A Comparative Study of RIPASA Score and ALVARADO Score in the Diagnosis of Acute Appendicitis. J Clin Diagn Res 2014;8:NC03-5.

15. Kalan M, Talbot D, Cunliffe WJ, Rich AJ. Evaluation of the modified Alvarado score in the diagnosis of acute appendicitis: a prospective study. Ann R Coll Surg Engl 1994;76:418-9.

16. Antevil JL, Rivera L, Langenberg BJ, Hahm G, Favata MA, Brown CV. Computed tomography-based clinical diagnostic pathway for acute appendicitis: prospective validation. J Am Coll Surg 2006;203:849-56

17. Owen TD, Williams H, Stiff G, Jenkinson LR, Rees BI. Evaluation of the Alvarado score in acute appendicitis. J R Soc Med 1992;85:87-8.

18. Dumlu EG, Tokaç M, Bozkurt B, Yildirim MB, Ergin M, Yalçin A, et al. Correlation between the serum and tissue levels of oxidative stress markers and the extent of inflammation in acute appendicitis. Clinics (Sao Paulo) 2014;69:677-82. Crossret

19. Kariman H, Shojaee M, Sabzghabaei A, Khatamian R, Derakhshanfar $\mathrm{H}$, Hatamabadi H. Evaluation of the Alvarado score in acute abdominal pain. Ulus Travma Acil Cerrahi Derg 2014;20:86-90. Crossret

20. Zielke A, Sitter H, Rampp TA, Schäfer E, Hasse C, Lorenz W, et al. Validation of a diagnostic scoring system (Ohmann score) in acute appendicitis. [Article in German] Chirurg 1999;70:777-84 [Abstract]

21. Zielke A, Sitter H, Rampp T, Bohrer T, Rothmund M. Clinical decisionmaking, ultrasonography, and scores for evaluation of suspected acute appendicitis. World J Surg 2001;25:578-84. Crossree

\title{
ORIJINAL ÇALIŞMA - ÖZET
}

\section{Alvarado ve Ohmann skorlamaları apandisit tanısında ve enflamasyonun şiddetinde gerçek yol gösterici olabilir mi?}

\section{Dr. Eyüp Murat Yılmaz,, ${ }^{1}$ Dr. Mücahit Kapçı, ${ }^{2}$ Dr. Sebahattin Çelik, ${ }^{3}$ Dr. Berke Manoğlu, ${ }^{4}$ Dr. Mücahit Avcil, ${ }^{2}$ Dr. Erkan Karacan ${ }^{1}$}

\author{
${ }^{1}$ Adnan Menderes Üniversitesi Tıp Fakültesi, Genel Cerrahi Anabilim Dalı, Aydın \\ ${ }^{2}$ Adnan Menderes Üniversitesi Tıp Fakültesi, Acil Tıp Anabilim Dalı, Aydın \\ ${ }^{3}$ Van Yüzüncü Yıl Üniversitesi Tıp Fakültesi, Genel Cerrahi Anabilim Dalı, Van \\ ${ }^{4}$ Aydın Devlet Hastanesi, Genel Cerrahi Kliniği, Aydın
}

AMAÇ: Akut apandisit cerrahi kliniklerinde görülen en yaygın karın ağrısı sebeplerinden birisidir. Tanı kolay konulabilse de özellikle premenopozal kadınlar ve yaşılıarda karıştıılabilmektedir. Bu sebeple mevcut bazı skorlama sistemlerinin hastalığın kolay tanı konabilmesine ve hastalığın enflamasyon şiddetine yol göstermesine katkııını araştırmak istedik.

GEREÇ VE YÖNTEM: Akut apandisit tanısı konan toplam 105 hasta çalışmaya dahil edildi. Alvarado ve Ohmann skorlamaları yapılan hastalara ultrasonografi yapılıp apendektomi uygulandı. Ameliyatta "intraoperatif şiddet skorlaması" uygulandı ve bu skorlamaların birbiriyle korelasyonu, Alvarado ve Ohmann skorlarının akut apandisiti ön görmede önemi araştııılı.

BULGULAR: Alvarado skoru ile, Ohmann skoru arasında pozitif yönde orta derecede korelasyon bulundu $(r=0.508, p<0.001)$. Histopatolojik sonuçlara göre Alvarado skorunun akut apandisit tanısını ön görme oranı istatistiksel olarak anlamlı iken ( $p=0.027)$ Ohmann skorlamasının ön görme oranı istatistiksel olarak anlamlı bulunmadı $(p=0.807)$. Ameliyatta şiddet skoruna bakıldığında ise, her iki skorun da ameliyat sırasında yapılan skorlama ile bağıntısı zayıf bulunurken Alvarado skorlaması ile intraoperatif şiddet skorlaması arasında anlamlılı saptandı $(r=0.30, p=0.002)$. Ohmann skorlaması ile intraoperatif şiddet skorlaması arasında anlamlıık saptanmadı $(r=0.09, p=0.384)$.

TARTIŞMA: Alvarado skorlaması akut apandisiti ön görme ve enflamasyon şiddeti hakkında fikir verebilirken, Ohmann skorlaması daha çok akut apandisiti dışlama konusunda fikir vermektedir.

Anahtar sözcükler: Alvarado; apandisit; enflamasyon; Ohmann.

Ulus Travma Acil Cerrahi Derg 2017;23(1):29-33 doi: 10.5505/tjtes.2016.89894 